\title{
Ethnologies
}

\section{Working Out in Japan: Shaping the Female Body in Tokyo Fitness Clubs. By Laura Spielvogel. (Durham and London, Duke University Press, 2003. Pp. xii + 250, ISBN 0-8223-3049-0)}

\section{Kristin Harris}

Volume 26, numéro 1, 2004

Littératie

Literacy

URI : https://id.erudit.org/iderudit/013349ar

DOI : https://doi.org/10.7202/013349ar

Aller au sommaire du numéro

\section{Éditeur(s)}

Association Canadienne d'Ethnologie et de Folklore

ISSN

1481-5974 (imprimé)

1708-0401 (numérique)

Découvrir la revue

Citer ce compte rendu

Harris, K. (2004). Compte rendu de [Working Out in Japan: Shaping the Female Body in Tokyo Fitness Clubs. By Laura Spielvogel. (Durham and London, Duke University Press, 2003. Pp. xii + 250, ISBN 0-8223-3049-0)]. Ethnologies, 26(1),

238-241. https://doi.org/10.7202/013349ar d'utilisation que vous pouvez consulter en ligne. 
The Folktale section presents Halpert's interest in tall tales and his resilient dedication to fieldwork in a variety of settings. It contains essays on tall tales that he collected in Indiana and in Ohio: "Liars' Club Tales" (1943) and "Folktales and Jests from Delaware, Ohio" (1948). These are intermixed with three essays on material that he collected while in the army and stationed in Alaska and Western Canada: "Tall Tales and Other Yarns from Calgary, Alberta" (1945), "The Cut-Off Head Frozen On: Some International Versions of a Tall Tale" (1979; 1985), and "Mosquitoes on the Runway" (1990). "The Cut-Off Head" is of particular interest because Halpert presents several variants of a motif that was not included in Thompson's type index. "Mosquitoes on the Runway" introduces us to an aspect of occupational folklore: airforce pilots speak of the remarkable similarities of mosquitoes in the north to P-39 Bell Aircobra one-man fighter planes. This is followed by "A Bibliographic Essay on the Folktale in English" (1982).

This collection ends with a bibliography of Halpert's works and his "Genre Classification for Individual Student Collections," a list which many in our discipline have encountered in one form or another through our folklore training. In addition to achieving their goals of publishing hard to find articles and of exhibiting some of Halpert's most influential essays, the editors have created a record of institutional history. This collection demonstrates many of the issues and changes in our discipline over the past sixty years. It presents a definition of folklore by example of what we have achieved, and thus should sit next to other foundational texts on folklore.

Cory W. Thorne University of Pennsylvania Philadelphia, PA

\section{Working Out in Japan: Shaping the Female Body in Tokyo Fitness Clubs.} By Laura Spielvogel. (Durham and London, Duke University Press, 2003. Pp. xii + 250, ISBN 0-8223-3049-0)

Adapted from Spielvogel's doctoral dissertation, Working Out in Japan is based on thirteen months of fieldwork conducted in two Tokyo health clubs in 1995. Spielvogel asserts, "the dual focus of this book... is the tension between the local and the ideological or, in this case, the grounded practices of the club and the larger constructions of beauty, health and leisure" (6). Indeed, throughout the text, the author manages 
to effectively problematize issues of health and fitness in Japanese culture within the context of health clubs.

Spielvogel immediately confesses her biases and personal connection to this work, which she admits likely assisted her greatly in completing the research in the first place. Her certification and previous experience as a fitness instructor in the U.S.A. paved the way for her to gain access, through paid employment, to two Japanese fitness clubs: one in downtown Tokyo, the other in the suburban, or "bedroom community" of Chiba. This skill and training begat a reciprocal relationship, whereby Spielvogel conducted extensive fieldwork with almost no limitations in these clubs, the clubs boasting a Western instructor with "American" steps and routines. Indeed, the author's balance between employee and researcher, as a Westerner living in the Far East, is revealed throughout the book, as Spielvogel incorporates Japanese words and phrases to help explain Japanese ideology. Further, she ofttimes compares Japan to the United States as a means of using "the long-standing and complicated relationships between these cultural paradigms to underlie and inform my understanding of the discipline and display of the female body in contemporary Japan" (5). Aside from the fact that the health club movement in Japan was largely influenced by increased popularity of aerobics in the United States, and the two are thus easily contrasted, Spielvogel uses comparisons sparingly and effectively.

While at first glance this book might appear to merely replicate previous studies of women and body image, Spielvogel uses her fieldwork within health clubs not just as a backdrop for her arguments, but as the locus of the discussion. Her examination of the physical layout, duties of employees, and activities of patrons are at the heart of this study, indeed identifying the complexities of everyday life at the health club within larger ideologies of health and beauty. As such, Spielvogel does achieve her stated goals.

Spielvogel's introduction clearly and concisely outlines her personal and theoretical approaches. Initially providing statistics to illustrate socioeconomic and gender factors in fitness clubs in Japan, Spielvogel proceeds to quantitative analysis and an introduction to her theoretical and methodological approaches. The author also discusses the two locations of her fieldwork, emphasizing the differences in clientele and attitude in the downtown core versus the suburban setting. Finally, she introduces Japanese attitudes towards health and fitness. Particularly 
interesting is her discussion of health, or genki, in Japan. This term means, "not only to be in good physiological health but to be well-adjusted, enthusiastic, self-sufficient, and passionate" (22). Health clubs in Japan therefore aim to fulfill those needs in their patrons, by not only providing a place to work out, but also entertainment and lifestyle activities, such as dances, weekend events, and even canteens with beer and icecream for post-workout indulgences. Finally, Spielvogel establishes notions of sexuality, beauty and the female body, and how further chapters will link these ideas with the aims and realities of health clubs.

The first chapter is dedicated to the history of aerobics in Japan, and this is where the most direct comparisons to the U.S.A. are made. Subtitled "The Sexy American Import", Spielvogel contextualizes the rise in popularity of health clubs in Japan by discussing militarization of sport, consumption of leisure services, and the role that sex plays in women's sports.

The two chapters that follow concentrate on discipline: discipline of space, and discipline of bodies. The author introduces the duality of Japanese fitness clubs as being places "constructed simultaneously as sites of discipline and spaces of luxury" (61). By examining the physical structure of the clubs, how they are maintained, and their emphasis both on hard work and relaxation, Spielvogel emphasizes the complexities of the space within the walls of fitness clubs, and the mixed messages it sends. Related to this is how bodies are regarded both within and outside the club itself. She argues that fitness instructors are held to an unrealistic ideal of fitness, thereby implying that a body that is not fit is, "synonymous with being unattractive, unhealthy, and unproductive by ideological, social and economic standards" (85). The link between fitness and attractiveness is certainly a familiar one. But what is interesting here is Spielvogel's conflation of health and beauty with unhealthy activities such as drinking, smoking and eating fatty foods, all within the realm of the fitness club. This discussion is continued in the fourth chapter, along with an analysis of gender inequities in the club environment.

The last two chapters focus on a more conventional analysis of the female body in Japan, and how this applies to the fitness club setting. Spielvogel found that Japanese standards of beauty, "revolve around youth, good proportions, shapely legs, and, above all, bone-thin skinniness" (143). She outlines various methods for achieving these 
ideals, such as dieting, skin lightening cream, leg saunas (made of heavy rubber to promote sweating and lose inches), cellulite cream and foundation garments. In Japan, to be youthful is not only to be beautiful, but to also be innocent and vulnerable. Therefore, great emphasis is placed not on feeling young, but looking young. The Japanese ideal of a perfectly proportioned body has also resulted in a mental segmentation of body parts, as legs or breasts or stomachs are selected as "problem areas" that need to be controlled. Skinniness is a contemporary ideal in Japan, as until the mid-twentieth century, "robustness as a sign of productivity and fertility" were favoured (174). Spielvogel argues that prosperity in contemporary Japanese society has led to the idea that to starve oneself is selfless, and that even though the average figure of a Japanese woman may seem thin to Western eyes, Japan's cultural standards may see that woman as heavy. She discusses the idea of thinness as ideal both within the culture of Japan, as well as cross-culturally by comparing it to the U.S.A. She points out that, even though dieting is seen as a positive move towards better health in Japan, indulging in forbidden foods may also be seen as a way to "claim identity and manipulate power" (181). Food is thereby linked not only to health and body image, but to feminine and individual power as well.

Spielvogel's brief conclusion brings her study full-circle, back to the American influence that started the initial fitness craze in Japan. She uses the more recent American fad of spinning classes, and its failure in health clubs in Japan, to illustrate "the incorporation of a Westernized stereotype of 'Eastern' philosophy, reinterpreted in a Japanese context" (210). Spinning classes emphasize high cardio intensity and simple choreography, the polar opposite of elements valued in Japanese fitness routines. Spielvogel concludes with the assertion of the Japanese fitness club as a unique and separate space where some cultural expectations are reinforced, and others inverted or subverted. Her interdisciplinary approach would prove useful to those in folklore, cultural studies, women's studies, and leisure/recreation studies. And it is this maintenance of the complexity of the topic at hand that makes this a satisfying read to the end, leaving the reader with a multi-layered understanding of how beauty, health, leisure and consumerism interact in the health club of Japan.

Kristin Harris Memorial University St. John's, Newfoundland 